Khazanah: Jurnal Studi Islam dan Humaniora

ISSN: 0215-837X (p); 2460-7606 (e), Vol. 19 (1), 2021, pp. 39-60

DOI: $10.18592 /$ khazanah.v19i1.4565

Submit: 28/03/2021 Review: 24/07/2021 Publish: 30/07/2021

\title{
SPIRITUALITAS DALAM SINKRETISME ISLAM DAN SAPTA DARMA
}

\author{
Wiwik Setiyani; Khoirun Nisa' \\ Universitas Islam Negeri Sunan Ampel Surabaya; \\ Universitas Gadjah Mada Yogyakarta \\ wiwiksetiyani@uinsby.ac.id; nitatasrif@gmail.com
}

\begin{abstract}
Every adherent of a religion or belief has a certain way to get closer to God. A strong desire to be close to God the creator of nature is a spirituality that can change buman behavior for the better. The meeting between Islam and Sapta Darma is a way to find inner calm which has the concept of physical and spiritual awareness. Hence this article wants to explain the form of syncretism between Islam and Sapta Darma in Surabaya in the form of prostration or ening. The prostration performed by Sapta Darma is not a prayer, but a special ritual of seeking tranquility in the experience of life as a cultural interpretation. Prostration in Islam is the implementation of prayer to get closer to Allah with the provisions taught in Islam. This study uses indepth interview as methodology to find the stage of religious maturity from the aspect of Shari'a and the implementation of religious teachings. This Research finds that, even though the syncretism between Islam and Sapta Darma is so pronounced but, this condition encourages its followers to maintain the two because they find what they want to achieve namely, balance and spiritual well-being. It shows that Islam and Sapta Darma are not as an escape but, as a way of life. This study also aims to provide a new perspective or paradigm in understanding religious concepts and spiritual values through syncretism between Islam and Sapta Darma. Syncretic diversity has been attached to society and has become the cultural identity of its locality.
\end{abstract}

Keywords: Islam; Sapta Darma; Sincretism; Spirituality

\begin{abstract}
Abstrak: Setiap penganut agama atau kepercayaan memiliki cara tertentu untuk mendekatkan diri dengan Tuhannya. Keinginan yang kuat untuk dekat dengan Tuhan pencipta alam merupakan spiritualitas yang mampu mengubah perilaku manusia menjadi lebih baik. Pertemuan antara Islam dan Sapta Darma menjadi jalan untuk menemukan ketenangan batin yang memiliki konsep kesadaran jasmani dan rohani. Artikel ini menjelaskan bentuk sinkretisme antara Islam dan Sapta Darma di Surabaya, dalam bentuk sujud atau ening. Sujud yang dilakukan Sapta Darma bukanlah pelaksanaan sholat tetapi, ritual khusus mencari ketenangan dalam pengalaman hidup sebagai interpretasi budaya. Sujud dalam Islam adalah pelaksanaan sholat untuk mendekatkan diri kepada Allab dengan ketentuan yang diajarkan dalam Islam. Studi ini menggunakan metode in-depth interview guna, menemukan tingkat kematangan dalam beragama dari aspek syariat dan implementasi ajaran agama. Temuan penelitian menunjukan, kendati sinkretisme antara Islam dan Sapta Darma begitu terasa namun, kondisi ini mendorong mereka tetap mempertahankan keduanya karena, menemukan apa yang ingin dicapai yaitu, keseimbangan dan kesejabteraan spiritualitas. Agama Islam dan Sapta Darma bukan sebagai pelarian hidup semata tetapi, paradigma baru untuk memahami konsep keberagamaan dan nilai-nilai spiritualitas umat beragama melalui sinkretisme Islam dan Sapta Darma. Keberagamaan sinkretis telah melekat pada masyarakat dan menjadi identitas budaya lokalitasnya.
\end{abstract}

Kata kunci: Islam; Sapta Darma; Sinkretisme; Spiritualitas 


\section{Pendahuluan}

Setiap penganut agama ingin merasakan kedamaian dan dekat dengan Tuhannya secara eksklusif tanpa adanya keraguan dan tekanan dalam beragama. Namun, proses sinkretisme agama di masa lampau masih sangat terasa pengaruhnya hingga hari ini. Akibatnya menyebabkan sebagian umat beragama mengalami kekhawatiran terhadap pilihan agamanya akibat kurangnya pemahaman terhadap agama yang dianut. Agama yang dipilih belum memberikan rasa aman, kedamaian dan ketenangan batin. Fungsi beragama adalah mencari ketenangan dan rasa aman sebagaimana hirarki kebutuhan dasar manusia. ${ }^{1}$ Sinkretisme memiliki ciri khas yang dikenal adaptif, akomodatif dan luwes antara satu keyakinan dengan keyakinan lain atau antara agama yang satu dengan agama yang lain. Kombinasi sempurna ini menjadikan paham sinkretisme melekat pada masyarakat Jawa karena ia telah mengakar kuat pada seluruh lapisan kehidupan masyarakatnya. ${ }^{2}$

Pada kasus Sapta Darma di Surabaya, penganut Islam melakukan perubahan keyakinan tanpa disadari. Bermula dari perkenalan dengan tokoh Sapta Darma dan merasakan kecocokan secara persuasif menimbulkan kepercayaan untuk mengikuti ajaran agamanya. ${ }^{3}$ Agama menarik perhatian masyarakat karena, memiliki dampak pada kehidupan manusia. Sementara sinkretisme membuat agama mengalami transformasi bentuk, menciptakan jarak dan mendorong umat beragama semakin menyadari identitasnya di tengah masyarakat dan budaya yang homogen. ${ }^{4}$ Pada akhirya krisis identitas tak terhindarkan dan berdampak pada proses penting yaitu, pencarian spiritualitas.

Perubahan pada cara pandang atau pola pikir bahkan, hal yang terpenting adalah merasakan nilai-nilai spiritualitas agama itu sendiri. Era modern spiritualitas memiliki peran dalam membangkitkan semangat hidup dan memenuhi kepuasan hati serta rasa keingintahuan, namun spiritualitas tidak lagi berhubungan dengan Tuhan. ${ }^{5}$ Artikel ini adalah jawaban atas hipotesis sederhana yakni, apakah spiritualitas yang dimaksud berhubungan dengan pengalaman keagamaan ataukah sebagai pelarian hidup?. Bagaimana bentuk sinkretisme agama antara penganut Islam dan Sapta Darma? dan Bagaimana sesungguhnya Sapta Darma yang berkembang di Surabaya?

Penelitian ini berpijak pada teori klasik Clifford Geertz yaitu agama sebagai sistem kebudayaan. ${ }^{6}$ Dalam konteks sosial-budaya dan agama, sangat sulit untuk

\footnotetext{
${ }^{1}$ Frank G. Gobble, Madrab Ketiga Psikologi Humanistik Abraham Maslow, (Jogjakarta: Kanisius, 2006), 278.

${ }^{2}$ Harry J. Benda, The Crescent And Rising Sun; Indonesian Islam Under Japanese Occupation, 19421945. The Hague and Bandung, W. Van Hoeve, 1958, 320 pp. (Book Reviews), 126-134.

${ }^{3}$ Rudi Sis, Wawancara, 12 Maret 2020.

${ }^{4}$ S. Bayu Wahyono, Kejawen dan Keislaman: Suatu Pertarungan Identitas. Jurnal Ilmu Sosial dan Politik, Vol 5, no, 1 (Juli 2001), 41-59.

${ }^{5}$ Ngainun Naim, "Kebangkitan Spiritualitas Masyarakat Modern," Kalam 7, No. 2 (December 31, 2013): 237-258.

${ }^{6}$ Cliffort Geertz, Religion of Java (University of Chicago Press, 1976), 89.
} 
memisahkan suatu budaya atau agama tertentu yang sudah menyatu dan melekat ke dalam budaya atau agama lain yang telah diserap dan dijadikan sebagai landasan dan inspirasi hidup masyarakatnya. ${ }^{7}$ Pendekatan yang digunakan Geertz berfungsi sebagai standar untuk melihat secara mendalam sinkretisme yang menjadi ciri khas masyarakat Jawa khususnya. Studi ini berusaha untuk menjelaskan bentuk sinkretisme antara Islam dan Sapta Darma dalam proses menemukan nilai-nilai spiritualitas melalui kacamata pemeluknya.

Penelitian tentang sinkretisme dan spiritualitas telah banyak dilakukan oleh peneliti sebelumnya. Mark Woodward ${ }^{8}$ dalam karya monumentalnya Islam Jawa: Kesalehan Normatif versus Kebatinan (1999) mengemukakan bahwa, spiritualitas berisi tentang keyakinan kepada Tuhan dan makna kehidupan yang luas, unik, complicated yang mengandung etika dan moralitas yang, terbingkai sempurna dalam sinkretisme yang penuh dengan belantara mistis. Secara general, spiritualitas tidak lagi membahas persoalan hubungan manusia dengan Tuhannya tetapi, dampak dari kedekatan dengan Tuhannya. Selain itu beberapa penulis berikut dijadikan bahan kajian atau pijakan dalam memahami spiritualitas secara mendalam. Kees De Jong, ${ }^{9}$ Shinya Masa'aki, ${ }^{10}$ Suhandi, ${ }^{11}$ David Tacey $^{12}$ mengambil fokus terhadap problem pemahaman keagamaan secara identitas dan keyakinannya. Spiritualitas memiliki nilai lebih tinggi daripada agama, karena itu spiritualitas mampu membawa perubahan pada sikap perilaku serta kepuasan batin, sehingga menempati posisi puncak dalam hidup manusia.

Artikel ini ingin menjelaskan problematika yang dihadapi para penganut Sapta Darma dengan latar belakang agama Islam. Namun, harus dihadapkan pada dua keyakinan yang mendorong mereka harus merangkul keduanya karena, menemukan apa yang ingin dicapai oleh setiap insan yaitu, kesejahteraan dan keseimbangan spiritualitas. Penelitian ini bertujuan untuk melihat bentuk sinkretisme antara Islam dan penganut Sapta Darma di Surabaya yang mencakup implementasi ajaran kedua agama dan spiritualitas yang dicapai kendati praktik kedua agama tersebut berbeda. Studi ini juga sebagai perspektif atau paradigma baru untuk memahami konsep keberagamaan dan nilai-nilai spiritualitas umat beragama. Islam tetap menjadi agama identitas dan menariknya Sapta Darma tetap dipertahankan dan menjadi spirit atau

${ }^{7}$ Daniel L. Pals, Seven Theories of Religion (Tujuh Teori Agama Paling Komprehensif). (Jogjakarta, IRCiSoD), 327-328.

${ }^{8}$ Mark, R. Woodward, Islam Jawa: Kesalehan Normatif versus Kebatinan. (Yogyakarta, LkiS, 1999).

${ }^{9}$ Kees de Jong, "Hidup Rukun Sebagai Orang Kristen Spiritualitas Dari Segi Theologia Religionum," Gema Teologi 30, no. 2 (October 10, 2006), 1-12.

${ }^{10}$ Shinya Masa'aki, "The Politico-Religious Dilemma of The Yasukuni Shrine," Politics and Religion Journal 4, no. 1 (2010), 41-55.

${ }^{11}$ Suhandi Suhandi, "Spiritualitas Agama Dan Masyarakat Modern (Eksistensi Tarekat Qadiriyah Wa Naqsyabandiyah Di Bandar Lampung)," Al-Adyan: Jurnal Studi Lintas Agama 14, no. 1 (June 30, 2019): 71-94.

${ }^{12}$ David John Tacey, The Spirituality Revolution: The Emergence of Contemporary Spirituality (Psychology Press, 2004).

Kharanah, Vol. 19 (1), 2021 
jalannya hidup. Islam maupun Sapta Darma adalah satu kesatuan yang menjadi jalan hidup (way of life) penganutnya dalam menemukan spiritualitas.

\section{Metode}

Metode penelitian menjadi unsur penting untuk melakukan proses penelitian. Penelitian ini adalah penelitian kualitatif, yakni jenis penelitian yang mendeskripsikan atau menjelaskan tentang konsep atau pendapat tanpa penghitungan angka-angka. Teknik penggalian data dilakukan dengan observasi dan interview mendalam guna mendapatkan data-data yang dibutuhkan. Penggalian data dengan metode kualitatif yakni, penelitian yang mengacu pada deskripsi dan menganalisis dengan teori dan data dengan teknik wawancara mendalam. ${ }^{13}$ Para informan yang dipilih adalah orangorang yang terlibat langsung dalam kegiatan Sapta Darma dan menganut agama Islam.

Informan menjadi sumber data penelitian yang menjadi kunci dalam menentukan validitas data. Berikut adalah informan yang memiliki dua keyakinan yakni, Islam dan Sapta Darma, diantaranya; Rudi Sis, Aryo Pandugo, Sugi Slamet, Nur Ratih dan Noviani. Informan tersebut salah satunya teridentifikasi sebagai pemimpin Sapta Darma, pengurus dan anggotanya. Sumber data dalam penelitian yang diperoleh harus dilakukan proses triangulasi, yakni untuk menyakinkan validitas data. ${ }^{14}$ Kroscek data melalui triangulasi menjadi sangat penting untuk menjaga kevalidan data penelitian.

\section{Pembahasan}

\section{Sosio-Religi Umat Sapta Darma di Surabaya}

Kehidupan sosial keagamaan Sapta Darma terbentuk dalam satu komunitas dengan beragam latar belakang. Kebanyakan mereka mengalami kesulitan hidup secara ekonomi, dari golongan masyarakat menengah ke bawah. ${ }^{15}$ Status sosial pada komunitas tersebut memiliki kesamaan dalam kehidupannya dan cenderung membentuk kelompok sosial tertentu. Fenomena sosial ini membentuk gerakan sosial yang memiliki beragam bentuk dengan latar belakang profesi, agama, suku, ras dan sampai pada persamaan status sosial ekonomi. ${ }^{16}$ Selain kesamaan status sosial ekonomi juga memiliki kesamaan latar belakang agama.

Para penganut Sapta Darma kebanyakan dari muslim, namun ada juga yang dari non- muslim. Keislaman para penganut Sapta Darma sangat beragam artinya,

\footnotetext{
${ }^{13}$ John Creswell, Qualitative Inquiry and Research Design, Choosing Among Five Approaches (London, Sage Publication, 2007, 2nd Edition), 15.

${ }^{14} \mathrm{P}$. Brink, Issues of Reliability and Validity, In Morse, J (ed)., Qualitative nursing research: A contemporary dialogue (London: Sage,1991). 164-186.

${ }^{15}$ Rudi Sis, Wawancara, Surabaya, 12 Maret 2020.

${ }^{16}$ Andi Haris, Asyraf Bin AB Rahman, and Wan Ibrahim Wan Ahmad, "Mengenal Gerakan Sosial dalam Perspektif Ilmu Sosial," Hasanuddin Journal of Sociology 1, no. 1 (July 3, 2019): 15-24.
} 
menganut Islam sejak kecil bahkan, ada yang dari pesantren. Secara umum mereka mampu membaca alquran yang dapat dibuktikan dengan melafalkan ayat-ayat alquran dan sebagian mampu menerjemahkan. ${ }^{17}$ Latar belakang tersebut disebabkan pola asuh orangtua dalam mendidik anaknya untuk belajar alquran tidak perlu diragukan. Sebagaimana pola asuh para orangtua mengedukasi anak membaca dan memahami alquran dapat dilakukan secara istiqomah sehingga, menjadi anak yang disiplin dan menjadi keteladanan yang baik. ${ }^{18}$

Penganut Sapta Darma juga memiliki beragam latar belakang pendidikan mulai sekolah dasar, pesantren sampai pendidikan tinggi. Heterogenitas pendidikan menjadi keunikan tersendiri karena, dapat berdampak pada argumen yang diberikan memilih Sapta Darma sebagai ajarannya. Alasan para penganut Sapta Darma diantaranya menjelaskan bahwa; "Islam merupakan agama yang murni, namun kami belum mendapat ketenangan batin karena sifat emosi yang masih tinggi, padahal kami sudah menjalankan ibadah sholat, puasa dan berdoa mohon ampunan."19 Pada konteks kehidupan beragama terkadang sulit membedakan agama yang murni dan hasil pemikiran atau interpretasi agama. Sesuatu yang murni berasal dari Tuhan, absolut dan sakral. Hasil pemikiran agama berasal selain Tuhan atau manusia bersifat temporal, berubah dan profane. ${ }^{20}$

Penganut Sapta Darma merasakan bahwa Islam itu merupakan agama yang memiliki banyak pertanyaan dan harus segera dicari solusinya. 'Perjalanan hidup mencari kebenaran spiritual sebagaimana para Nabi dan Rasul terdahulu, kegalauan mencari kebenaran yang hakiki menurut Allah itu seperti apa dan ternyata semua ada di Sapta Darma melalui sujud Ening. ${ }^{21}$ Sesungguhnya apa yang dapat dilihat, didengar, disentuh dan dirasakan secara lahiriyah melampaui keajaiban yang terukur. Manusia biasa memiliki persepsi yang berbeda bahkan seorang spesialis sekalipun, objektif dan subjektif, lahiriyah dan batiniyah akan bercampur aduk dan menghasilkan imajinasi, ${ }^{22}$ dan pilihan manusia melalui pencarian kebenaran inilah yang dapat menimbulkan beragam penafsiran.

Penganut Sapta Darma juga mengklaim bahwa, 'Islam merupakan agama yang memiliki cukup banyak cobaan karena, semenjak beragama Islam tidak pernah mendapatkan kemudahan padahal usaha dilakukan terus menerus dan berulang-ulang tetapi tidak mendapatkan hasil.. ${ }^{23}$ Karena itu, dilema keberagamaan Sapta Darma ${ }^{24}$

${ }^{17}$ Rudi Sis, Wawancara, Surabaya, 13 Maret 2020

${ }^{18}$ Mahmud Mahmud, "Pola Asuh Orang Tua Dalam Membina Kemampuan Membaca AlQuran Pada Anak Di Desa Padang Tanggul Kecamatan Amuntai Selatan," Al Qalam: Jurnal Ilmiah Keagamaan dan Kemasyarakatan 14, no. 1 (June 1, 2020): 95-108.

${ }^{19}$ Aryo Pandugo, Wawancara, Surabaya, 24 Maret 2020.

${ }^{20}$ Nurdinah Muhammad, "Memahami Konsep Sakral dan Profan dalam Agama-Agama," Substantia: Jurnal Ilmu-Ilmu Ushuluddin 15, no. 2 (October 15, 2013): 266-278.

${ }^{21}$ Rudi Sis, Wawancara, Surabaya, 25 April 2020.

${ }^{22}$ Carl Gustav Jung, The Spirit in Man, Art, and Literature: Betapa Dabsyatnya Spirit Manusia terj. Subhan, (Yogyakarta: IRCiSoD, 2019), 194.

${ }^{23}$ Noviani, Wawancara, Surabaya,17 Maret 2020

Khazanah, Vol. 19 (1), 2021 
terjadi yang disebabkan cobaan hidup manusia yang datang bertubi-tubi dapat mengakibatkan stress atau tidak mampu mengelola hati dengan baik. Karena itu, diperlukan cara yang tepat dalam mengelola hati melalui keikhlasan dan kesabaran, bersyukur dan berserah diri kepada Allah. ${ }^{25}$

Alasan penganut Sapta Darma yang beragam inilah maka, sangat penting mengetahui bagaimana sesungguhnya Sapta Darma yang berkembang di Surabaya. Secara singkat Sapta Darma didirikan di desa Koplakan Pare Kediri Jawa Timur oleh Hardjosapoero yang namanya diganti dengan Panuntun Agung Sri Gutomo pada tanggal 27 Desember $1955 .{ }^{26}$ Sapta Darma di Surabaya terdapat beragam komunitas dengan membentuk kelompok-kelompok kecil melalui sanggar (tempat berkumpulnya komunitas Sapta Darma). Pengikut Sapta Darma di tengah pluralitas terbatas menjadi resisten dengan kelompok mayoritas yang tampak eksklusif namun, faktanya Sapta Darma mengklaim bahwa pluralitas hanya untuk kelompok agama besar. $^{27}$

Bagi penganut Sapta Darma menganut agama adalah formalitas, yang terpenting adalah merasakan spiritualitas dari ajaran agama serta berdampak pada kehidupannya. Identitas agama adalah formalitas sebagaimana tertuang pada kartu tanda penduduk (KTP) dan Islam menjadi agama yang tertulis di kartu tersebut dimaknai sebagai berserah diri bukan agama. ${ }^{28}$ Identitas agama memiliki signifikansi terhadap identitas diri seseorang, identitas keagamaan secara internal akan membentuk kepribadian para pengikutnya ${ }^{29}$ dan secara eksternal menjadi eksklusif atau menjadi perhatian masyarakat karena perbedaannya.

Formalitas agama menganut Islam adalah sebagai simbol agama namun, juga tetap menjalankan ajaran sebagaimana melaksanakan ibadah sholat, puasa dan berzakat. Karena, secara non formal Sapta Darma adalah keyakinan agama atau spiritnya. $^{30}$ Formalitas dan non formal menjadi kunci untuk tetap memegang keyakinan dan menghadapi dunia luar. Agama dibentuk sejak kecil dari edukasi orangtua namun, setelah beranjak memasuki dunia pendidikan dibentuk oleh sekolah baik di pesantren maupun sekolah agama atau umum. Sebagaimana wajah pendidikan Islam Indonesia berkembang sesuai kebutuhan dan tuntutan zaman khususnya,

${ }^{24}$ Wiwik Setiyani Khasbullah, "Dilema Keberagamaan Muslim Pengikut Sapta Darma Dalam Menemukan Nilai-Nilai Spiritualitas,” Religi: Jurnal Studi Agama-agama 16, no. 2 (August 30, 2020): 167187.

${ }^{25}$ Susatyo Yuwono, Mengelola Stres Dalam Perspektif Islam Dan Psikologi, Psycho Idea 8, no. 2 (July 1, 2010), 14-26.

${ }^{26}$ Imam Budi Santoso, Nasehat Orang Jawa (Yogyakarta: Divapress, 2010), 149.

${ }^{27}$ Jayyidan Falakhi Mawaza and Rohit Mahatir Manese, "Pengikut Sapta Darma di Tengah Pluralitas Terbatas," Palita: Journal of Social Religion Research 5, no. 1 (April 26, 2020): 49-64-64.

${ }^{28}$ Sugi Slamet, Wawancara, Surabaya, 15 April 2020.

${ }^{29}$ Sri Wahyuningsih R. Saleh, Nurul Aini Pakaya, and Chaterina Putri Doni, "Pembentukan Identitas Keagamaan Mahasiswi Bercadar di Perguruan Tinggi Agama Islam di Gorontalo,” Madani 1, no. 2 (December 7, 2019): 110-122.

${ }^{30}$ Sugi Slamet, Wawancara, Surabaya, 16 April 2020 
pendidikan Islam formal sesuai dengan kebijakan pemerintah dengan ciri khas tertentu. ${ }^{31}$ Sapta Darma bukanlah agama yang dibentuk dari agama mayoritas yang luput dari perhatian pemerintah, karena Sapta Darma bukanlah agama sebagaimana ditetapkan pemerintah, tetapi diakomodir sebagai aliran kepercayaan masyarakat termasuk aliran Ahmadiyah yang fenomenal.

Ketertarikannya terhadap Sapta Darma yang diinisiasi bapak Rudi Sis adalah sikapnya yang ramah dan santun kepada setiap orang. Beliau yang membentuk komunitas Sapta Darma di Surabaya yang bertempat di Sanggar. ${ }^{32}$ Kesantunan dan keramahan adalah representasi kepribadian yang memiliki sikap keagamaan yang tinggi. Beragama berarti mampu mengenal diri sendiri untuk menjadi pribadi yang sesuai dengan tuntunan agama, karena agama sebagai perilaku. ${ }^{33}$ Sapta Darma mengajarkan berbudi luhur dan mengenal diri sendiri selanjutnya dapat mengenal sang Hyang Widhi Wasa atau mengenal Tuhannya. ${ }^{34}$

Mengenal diri sendiri dan memiliki ketenangan menjadi tujuan dari ajaran Sapta Darma yakni, dengan konsep manusia melalui kesadaran jasmani dan rohani untuk memiliki nilai-nilai moral..$^{35}$ Pencarian menemukan kesadaran diri dilakukan tokoh Sapta Darma Surabaya yang menjelaskan pencarian masuk Sapta Darma adalah "perjalanan hidup saya mencari kebenaran spiritual sebagaimana para Nabi dan Rasul terdahulu. ${ }^{36}$ Kegalauan para Nabi dan Rasul mencari kebenaran yang hakiki menurut Allah itu seperti apa? Contoh, mengapa ada namanya agama Majusi (Zarathustra), ${ }^{37}$ agama tauhid (Ibrahim), Yahudi (Musa), Nasrani (Isa) dan Islam (Muhammad saw.)? Seakan-akan Allah membuat research kepada para Nabinya untuk memberikan agama yang berbeda? Seorang muslim harus terus berfikir dan mencari jawaban atau problem tersebut. Dengan sifat Allah Yang Maha Rahman dan Rahim (Kasih dan Sayang) tentu menunjukkan agama yang paling benar diantara agama tersebut. Kegigihan penganut Sapta Darma dalam menemukan agama tidak merujuk pada agama yang dimaksud, tetapi disebabkan memiliki berbagai latar belakang agama muslim maupun non-muslim.

Keragaman latar belakang para penganut Sapta Darma tidak hanya terkait agama sebelumnya tetapi juga, terkait status sosial, pendidikan, ekonomi maupun

\footnotetext{
${ }^{31}$ Muhammad Sya'roni, “Wajah Pendidikan Islam Indonesia,” Cendekia 7, no. 01 (May 2, 2015): $15-55$.

${ }^{32}$ Nur Ratih, Wawancara, Surabaya, 25 April 2020.

${ }^{33}$ Wiwik Setiyani, "Agama Sebagai Perilaku Berbasis Harmoni Sosial; Implementasi Service Learning Mata Kuliah Psikologi Agama," Community Engagement (2016): 26.

${ }^{34}$ Rudi Sis, Wawancara, Surabaya, 17 April 2020.

${ }^{35}$ Putri Chikmawati, "Konsep Manusia Dalam Ajaran Sapta Darma Dan Pemikiran Drijarkara" (undergraduate, UIN Sunan Ampel Surabaya, 2018), accessed July 5, 2020, http://digilib.uinsby.ac.id/23120/.

${ }^{36}$ Rudy Sis, Wawancara, Surabaya, 22 April 2020

${ }^{37}$ Khoirun Nisa Urrozi, “Agama Majusi dalam Tinjauan Hadis,” Religious: Jurnal Studi AgamaAgama dan Lintas Budaya 3, no. 2 (November 13, 2019): 147-60, https://doi.org/10.15575/rjsalb.v3i2.4404.
} 
profesi. Perbedaan tersebut melahirkan sebuah solidaritas yang kuat yang disebabkan kegalauan hati yang belum menemukan hakekat hidup dalam beragama. Mengenal sosio-religi Sapta Darma mengajarkan kehidupan yang damai dan tentram 'guyub rukun'. ${ }^{38}$ Kerukunan Sapta Darma dapat mewarnai kehidupan masyarakat Surabaya yang unik untuk diteliti dan dapat dijadikan pijakan dalam membangun sosial keagamaan.

\section{Implementasi Ajaran Islam dan Sapta Darma}

Setiap agama memiliki ajaran yang harus dilaksanakan oleh penganutnya. Agama tanpa praktik keagamaan akan terasa kering dan hampa. Masuk Islam artinya harus melaksanakan rukun Islam yakni: syahadat, sholat, puasa, zakat dan ibadah haji bagi yang mampu. Islam sebagai agama yang memiliki kesempurnaan harus diyakini oleh penganutnya dan diimplementasikan dalam kehidupan masyarakat. Syariat Islam harus ditegakkan dan dilaksanakan sebagaimana yang dilakukan oleh lembaga adat yang memiliki kontribusi untuk tegaknya syariat Islam. ${ }^{39}$ Menegakkan ajaran Islam menjadi syarat mutlak bagi seorang muslim.

Syariat Islam menjadi pondasi utama sebagaimana diatur dalam Islam. Syahadat berarti telah bersaksi bahwa tidak ada Tuhan selain Allah dan nabi Muhammad adalah utusan Allah. Kalimat tersebut wajib diucapkan dihayati dan dilaksanakan serta disaksikan oleh orang lain khususnya bagi mualaf. Setelah konversi, mualaf mendapatkan pembinaan agar, tetap terjaga keimanannya dan mendapatkan perlindungan serta kebebasan memeluk agama. ${ }^{40}$ Pembinaan bagi mualaf menjadi solusi praktis agar, tidak terjadi kesalahan dalam menjalankan Syariat Islam

Sholat menjadi kunci bagi umat Islam karena itu, kaifiatus sholat atau tata acara sholat diajarkan sejak anak-anak sehingga, akan melekat dan menjadi pondasi dasar melaksanakan ibadah sholat. ${ }^{41}$ Sholat memiliki fungsi membentuk manusia disiplin dan istiqomah bertanggungjawab bahkan, dapat meningkatkan kecerdasan emosional atau pengendalian diri lebih dari dapat menyehatkan tubuh dan jiwa. ${ }^{42}$ Kompleksitas fungsi shalat yang dapat diperoleh bagi muslim dapat meningkatkan kualitas keimanan dan dapat melaksanakan ibadah lain yakni, berzakat.

\footnotetext{
${ }^{38}$ Ida Bagus Gede Bawa Adnyana, I Kadek Adhi Dwipayana, Nilai sosio-Religius Ajaran Siwa Buddha Dalam Kakawin Sutasoma Karya Mpu Tantular, Jurnal Guna Widya, Volume 6, no. 2 (2019), 26-37.

${ }^{39}$ Abdul Wahid, "Kontribusi Lembaga Adat dalam Implementasi Syariat Islam di Aceh," Jurnal Ilmiah Mizani: Wacana Hukum, Ekonomi Dan Keagamaan 6, no. 2 (December 31, 2019): 151-160.

${ }^{40}$ Arafat Noer Abdillah, "Pemberdayaan Mualaf Pasca Konversi Di Mualaf Center Yogyakarta," Jurnal Tarbiyatuna 11, no. 1 (June 1, 2020): 23-30.

${ }^{41}$ Endang Switri, Apriyanti Apriyanti, and Sri Safrina, "Pembinaan Ibadah Shalat (Kaifiatus Sholah / Tata Cara Shalat) Pada Tpa Zuryati Di Masjid Ummu Massaid Komplek Perumahan The Green Indralaya," Jurnal Anadara Pengabdian Kepada Masyarakat 1, no. 2 (September 25, 2019), 152-157.

${ }^{42}$ Royanulloh and Budi Yahya Haerudin, "Rutinitas Shalat Sebagai Penguat Self Control Untuk Meningkatkan Kualitas Kesehatan Jiwa," Madani 1, no. 2 (December 7, 2019): 172-183.
} 
Syariat Islam yang tercermin dalam rukun Islam ketiga adalah zakat yang wajib dikeluarkan bagi seorang muslim. Zakat merupakan kewajiban muslim khususnya pada saat bulan ramadhan yakni; zakat fitrah dan harus disegerakan. ${ }^{43}$ Bentuk-bentuk zakat lainnya adalah zakat mal dan sejenisnya seperti; infaq dan shadaqah. Implementasi zakat sebagaimana tertuang dalam alquran adalah untuk mengentaskan kemiskinan ${ }^{44}$ bagi umat Islam dengan semangat berbagi untuk mereka yang membutuhkan sebagaimana diatur ketentuan yang berhak menerima zakat.

Prinsip Islam yang terakhir atau kelima adalah ibadah haji. Pelaksanaan ibadah haji diwajibkan bagi muslim yang mampu secara ekonomi dan yang ditinggalkan tercukupi. Secara detail ibadah haji memiliki syarat-syarat yang harus dipenuhi diantaranya; muslim, berakal, baligh, sehat dan mampu memahami pelaksanaan rukun haji (dengan bimbingan haji). ${ }^{45}$ Ibadah haji menjadi harapan bagi muslim karena, memiliki makna menyempurnakan rukun Islam. Selain rukun Islam seorang muslim harus mengimani yang terangkum dalam rukun iman.

Keimanan seorang muslim terhadap rukun iman disebut dengan mukmin berarti mengimani apa saja yang terangkum di dalamnya diantaranya; pertama, percaya kepada Allah. Kedua, percaya kepada malaikat Allah. Ketiga, percaya kepada para nabi atau utusan Allah. Keempat, percaya kepada kitab-kitab Allah. Kelima, percaya kepada hari akhir. Keenam, percaya kepada qodho dan qodar Allah. ${ }^{46}$ Keimanan muslim terhadap rukun iman harus tertanam sejak kecil sebagai pondasi dasar Islam agar, tidak mudah rapuh.

Penjelasan terhadap rukun iman tentang menyakini bahwa, tidak ada Tuhan selain Allah dan tidak ada yang disembah kecuali Allah. Ayat alquran yang menjelaskan tentang keimanan kepada Allah salah satunya dalam surat al-Ikhlas. ${ }^{47}$ Pembentukan keimanan kepada Allah diajarkan sejak usia dini melalui pembelajaran guna, menumbuhkan rasa dekat dengan Allah dan merasakan bersama dengan Allah dan yang terpenting selalu minta pertolongan Allah. ${ }^{48}$ Keimanan selanjutnya adalah percaya kepada Malaikat Allah. Seorang mukmin harus mengimani dengan cara memahami dan meneladani sifat-sifat malaikat yang senantiasa taat dan patuh tidak

\footnotetext{
${ }^{43}$ Ronny Mahmuddin et al., "Hukum Menyegerakan Penyerahan Zakat Harta dan Zakat Fitrah di Saat Pandemi Covid-19," Bustanul Fuqaha: Jurnal Bidang Hukum Islam 1, no. 2 (May 5, 2020): 125-136.

${ }^{44}$ Junaidi Safitri, "Implementasi Konsep Zakat Dalam Al-Qur'an Sebagai Upaya Mengentaskan Kemiskinan di Indonesia," At-Tasyri' (January 28, 2018): 1-15.

${ }^{45}$ Achmad Muchaddam Fahham, "Penyelenggaraan Ibadah Haji: Masalah dan Penanganannya," Kajian 20, no. 3 (September 19, 2016): 201-218.

${ }^{46}$ Maulana Muhammad Ali et al., Islamologi: Panduan Lengkap Memahami Sumber Ajaran Islam, Rukun Iman, Hukum \& Syariat Islam terj. Kaelan dari Religion of Islam (Jakarta: Darul al Kutub Islamiyah, 2016).

${ }^{47}$ Alquran; 112: 1-4.

${ }^{48}$ Allinda Hamidah, "Pembentukan Keimanan Kepada Allah Berbasis Prophetic Learning Untuk Siswa Sekolah Dasar," Cendekia 10, no. 01 (March 23, 2018): 15-28.
}

Kharanah, Vol. 19 (1), 2021 
pernah melakukan kesalahan. ${ }^{49}$ Allah menciptakan malaikat memiliki keistimewaan masing-masing, salah satu diantaranya keistimewaan yang dimiliki malaikat Jibril. Keistimewaannya adalah malaikat Jibril paling dekat dengan Allah dan sangat dekat dengan Rasulullah Nabi Muhammad saw. bahkan, malaikat Jibril disebut sebagai kepalanya malaikat. ${ }^{50}$ Mengimani malaikat belum sempurna menjadi mukmin maka, harus mengimani kitab-kitab Allah.

Kitab-kitab Allah yang telah diturunkan diantaranya: kitab taurat kepada dan nabi Musa, kitab zabur Daud, kitab injil kepada nabi Isa dan kitab alquran kepada nabi Muhammad. Islam menjadi agama penyempurna dari agama-agama sebelumnya. $^{51}$ Istilah Islam dalam alquran memiliki makna berserah diri, menundukkan wajah. Alquran menjadi pedoman umat Islam dalam menjalani kehidupan yang mengatur tentang hukum, keselamatan dunia akhirat dan agama yang benar dan penyempurna. ${ }^{52}$ Islam menyempurnakan agama-agama sebelumnya sebagaimana meyakini kitab-kitab Allah dan juga para utusannya Rasulullah.

Mengimani para utusan Allah yakni, manusia yang terpilih memiliki keluhuran budi pekerti atau sifat-sifat abklakul karimah. Para nabi memiliki jarak atau selisih sebagaimana yang diketahui ada 25 nabi dan 4 yang mendapatkan amanah wahyu Allah berupa kitab-kitab suci Allah (taurat, zabur, injil dan alquran). ${ }^{53}$ Para utusan Allah tersebut dituangkan dalam alquran yakni setiap utusan untuk menyeru umatnya menyembah pada Allah namun, sebagian mengikuti petunjuk dan sebagian yang lain mengingkari. ${ }^{54}$ Keimanan hari akhir merupakan kepercayaan yang harus dimiliki seorang mukmin karena, manusia harus mempertanggungjawabkan seluruh perbuatannya di akhirat kelak.

Hari akhir akan terjadi dengan ditandai berbagai kejadian yang tidak wajar, sebagai bentuk peringatan manusia atau umat Islam $^{55}$ untuk senantiasa berpegang pada tali Allah. Kejadian hari akhir, kapan terjadinya tidak ada satupun umat manusia yang tahu karena, pengetahuan tentang hari akhir adalah perkaran yang gaib dan hanya Allah yang mengetahui. ${ }^{56}$ Selanjutnya mengimani rukun iman yang keenam adalah percaya kepada qadha dan qadar Allah. Qadha bermakna sesuatu yang sudah

\footnotetext{
${ }^{49}$ Mulyana Abdullah, "Meneladani Sifat-Sifat Malaikat Allah Sebagai Bentuk Mengimani Adanya Malaikat" 16, no. 2 (2018): 10.

${ }^{50}$ Abd Kahar, "Eksistensi Dan Keistimewaan Malaikat Jibril AS Dalam Al-Qur'an," Jurnal Pemikiran dan Ilmu Keislaman 2, no. 1 (September 15, 2018): 283-325.

${ }^{51}$ Alquran: 5: 3.

${ }^{52}$ Andi Eka Putra, "Konsep Ahlul Al-Kitab Dalam Al-Qur'an Menurut Penafsiran Muhammed Arkoun Dan Nurcholish Madjid (Sebuah Telaah Perbandingan)," Al-D zilkra: Jurnal Studi Ilmu al-Qur'an dan al-Hadits 10, no. 1 (2016), 23-36.

${ }^{53}$ Jihad Muhammad Hajjaj, Umur dan Silsilah Para Nabi (Qisthi Press, 2016).

${ }^{54}$ Alquran: 16: 36.

${ }^{55} \mathrm{Abu}$ Fatiah Al Adnani \& Abdur Rahman Al-Wasithi, Renungan Akhir Zaman (QultumMedia, 2008).

${ }^{56}$ Alquran: 7: 187.
} 
ditetapkan dan qadar sesuatu yang telah ditentukan sejak azali. ${ }^{57}$ Allah yang menghendaki, menetapkan dan memutuskan semua makhluknya. Keduanya tidak bisa dipisahkan yang saling berkaitan.

Implementasi ajaran Islam membentuk manusia memiliki akhlakul karimah karena, pembiasaan melaksanakan ibadah yang dilakukan. ${ }^{58}$ Kebiasaan melaksanakan rutinitas ritual ibadah melahirkan sikap dan perilaku kedisiplinan dengan respon positif. Alquran dan hadis sebagai pedoman hidup bagi umat Islam menjadi sumber pengetahuan umat Islam agar, memiliki arah kehidupan yang terukur dan senantiasa mensyukuri nikmat Allah, ${ }^{59}$ hanya kepada Allah harus berserah diri dan memohon pertolongannya. Namun, tidak semua umat Islam mampu menjaga alquran dan hadis sebagai pedomannya, karena masih ada umat Islam yang menganut dua agama sekaligus yakni, Sapta Darma.

Sapta Darma memiliki ajaran yang dilaksanakan oleh penganutnya, bentuk ajaran Sapta Darma adalah melakukan ening atau sujud yang ditujukan kepada Tuhan Yang Maha Esa. Terdapat lima nama yang harus disebut dalam ritual ening yakni; Allah Hyang Maha Agung, Allah Hyang Maha Rokhim, Allah Hyang Maha Adil, Allah Hyang Maha Wasesa (Penguasa Semesta) Dan Allah Hyang Maha Langgeng. ${ }^{60}$ Beribadah memerlukan perjuangan kepasrahan dan keikhlasan untuk istiqamah atau secara rutin. Teologi ibadah merupakan sebuah perencanaan atau persiapan yang akan dilaksanakan ${ }^{61}$ dan tujuan dari ibadah sendiri mendekatkan diri kepada Allah. Para penganut Sapta Darma menemukan pencapaian diri melalui ening atau sujud guna mendapatkan pencapaian spiritual yang baik ${ }^{62}$ sehingga tercipta kesejahteraan spiritualitas yang kokoh (spiritual well-being). ${ }^{63}$

Ajaran Sapta Darma adalah; pertama, menanamkan kepercayaan Allah Yang Maha Kuasa adalah Esa. Kedua, melatih kesempurnaan sujud atau berbaktinya manusia kepada Sang hyang Maha Kuasa untuk mencapai budi luhur. Ketiga,

${ }^{57}$ Ibnul Qayyim al-Jauziyyah, Qada dan Qadar (Qisthi Press, 2016).

${ }^{58}$ Anwar Ibrahim, Muhammad Sarbini, and Ali Maulida, "Implementasi Metode Pembiasaan Shalat Tahajud dan Puasa Senin-Kamis Pada Pembentukan Akhlak Karimah Di Sekolah Unggulan Islami (Suis) Leuwiliang Bogor," Prosa PAI : Prosiding Al Hidayah Pendidikan Agama Islam 1, no. 2B (April 16, 2019): 130-143.

${ }^{59}$ Assingkily, "Living Qur'an dan Hadis di MI Nurul Ummah (Rutinitas, Ritual Ibadah Dan Pembinaan Akhlak) AR-RIAYAH,"4, no. 1 (2020) 12-29.

${ }^{60}$ Andriawan Bagus Hantoro and Abraham Nurcahyo, "Studi Perkembangan Aliran Kebatinan Kerohanian Sapta Darma Di Kabupaten Magetan Tahun 1956-2011," Agastya: Jurnal Sejarah Dan Pembelajarannya 4, no. 02 (July 10, 2014): 54-73.

${ }^{61}$ Debora Nugrahenny Christimoty, "Teologi Ibadah dan Kualitas Penyelenggaraan Ibadah: Sebuah Pengantar," Pasca: Jurnal Teologi dan Pendidikan Agama Kristen 15, no. 1 (November 30, 2019): 17 .

${ }^{62} \mathrm{Ni}$ Made Rasmi Himawari, Titik Muti'ah, and Hartosujono Hartosujono, "Spiritual WellBeing Penganut Aliran Kepercayaan Sapta Darma," Jurnal Spirits 9, no. 2 (December 26, 2019): 63-7474.

${ }^{63}$ Chirico Francesco, "Spiritual Well-Being In 21 st Century: It Is Time to Review the Current WHO's Health Definition" Journal of Health and Social Science 1, no. 1 (March 15, 2016): 11-16.

Kharanah, Vol. 19 (1), 2021 
mendidik manusia bertindak suci dan jujur budi pekerti. Keempat, mengajar warganya untuk mengatur hidupnya. Kelima, menjalankan wewarah tujuh. Keenam, memberantas segala bentuk takhayul. ${ }^{64}$ Inti dari ajaran Sapta Darma adalah tali rasa menentramkan pikiran dengan pola perilaku yang religious dengan cara menghilangkan kelelahan atau tukar hawa, ulah rasa dan racut bersatu dengan roh suci. ${ }^{65}$

Ajaran Sapta Darma memprioritaskan 'ening' yakni, sujud dengan melafadzkan 'Sang Hyang Widhi Wasa atau Allah Yang Maha Agung, Allah Yang Maha Rahim dan Allah Yang Maha Adil. ${ }^{66}$ Kegiatan sujud dilakukan oleh penganut Sapta Darma sebagai bentuk kesetiaan kepada Tuhan Hyang Maha Agung. Konsep Tuhan dalam Sapta Darma sederhana dan abstrak yakni, dengan mengedepankan konsep diri dengan perilaku yang suka menolong orang lain tanpa berharap imbalan (kebajikan). ${ }^{67}$ Sapta Darma memfokuskan pada samadi untuk olah rasa dan olah raga melalui laku spiritual yakni, ritual sujud, racut dan ening. ${ }^{68}$

Ajaran Islam dan Sapta Darma memiliki signifikansi masing-masing pada aspek syariat maupun pelaksanaan ritual ibadahnya. Setiap ajaran agama atau apapun namanya memiliki dampak pada spiritual masing-masing penganut agama. Agama mengajarkan manusia untuk tunduk, patuh dan disiplin dengan aturan-aturan yang mengikat pada setiap penganut agama. Setiap penganut agama melakukan transformasi dalam memahami agama, tidak hanya dalam konteks ibadah tetapi, nilainilai ibadah dapat diimplementasikan dalam kehidupan sehari-hari. ${ }^{69}$ Implementasi ajaran agama memiliki tujuan membangun kesadaran diri dalam merespons lingkungan sekitar, namun mengalami kebimbangan dalam memilih agama yang mana sebagai identitasnya.

\section{Titik Temu Agama dan Budaya}

Sinkretisme merupakan perpaduan unsur-unsur kepercayaan atau keyakinan suatu budaya atau agama yang melahirkan budaya atau agama baru yang disebut

\footnotetext{
${ }^{64}$ Nur Arifin, "Motif Bergabung Dalam Aliran Sapta Darma Pengikut Ajaran di Sanggar Agung Candi Sapta Rengga Yogyakarta," Jurnal Sosiologi Agama 11, no. 1 (January 21, 2018): 35-56.

${ }^{65}$ Reni Tiyu Wijayanti, "Pola Perilaku Religius Aliran Kepercayaan Masyarakat Kerokhanian Sapta Darma di Desa Brengkelan Kecamatan Purworejo Kabupaten Purworejo," Aditya - Pendidikan Bahasa dan Sastra Jawa 3, no. 3 (October 28, 2013): 52-57.

${ }^{66}$ Abas Sambas, Konsepsi Wahyu dalam Ajaran Sapta Darma, Skripsi (Jakarta: UINSAHIDA, 2011), 44. http://repository.uinjkt.ac.id/dspace/bitstream/123456789/6123/1/ABAS\%20SAMBASFUH.pdf

${ }^{67}$ Athaya Saraswati and Afrilia Sekar Dewanti, "Stereotip terhadap Aliran Penghayat Sapta Dharma dan Usaha Penganut Sapta Dharma mengatasinya melalui Konsep Diri," Jurnal Audiens 1, no. 1 (March 11, 2020): 58-64.

${ }^{68}$ Muh. Luthfi Anshori, “Laku Spiritual Penganut Ajaran Kerokhanian 'Sapta Darma' (Kasus Sanggar Candi Busono Kec. Kedung Mundu, Semarang)" (other, Universitas Negeri Semarang, 2013), accessed July 5, 2020, https://lib.unnes.ac.id/18191/.

${ }^{69}$ Ernita Dewi, “Transformasi Sosial dan Nilai Agama," Substantia: Jurnal Ilmu-Ilmu Ushuluddin 14, no. 1 (April 11, 2012): 112-121.
} 
dengan religi. Islam Jawa adalah representasi dari agama yang mengalami proses sinkretik ${ }^{70}$ Dalam paham sinkretisme agama-agama dunia seperti Islam atau Kristen misalnya, dianggap sudah kehilangan wajah aslinya. Hal ini disebabkan oleh proses percampuran dengan unsur luar yang, membuat suatu agama tampil bukan dengan wujud sejatinya sebagaima Islam di tanah Arab atau Timur Tengah. ${ }^{71}$ Agama didefinisikan sebagai aturan atau tata cara yang mengatur kehidupan manusia. Memahami agama memerlukan seperangkat kerangka berpikir yang cermat karena, akan selalu timbul dikotomi agama wahyu dan agama kebudayaan. ${ }^{72}$ Bagi seorang muslim agama wahyu tentu sebagaimana yang tersurat dalam alquran yakni: Yahudi, Nasrani dan Islam. Ketiga agama samawi tersebut senantiasa bersentuhan sebagai relasi wahyu namun, berbeda dalam konsepnya. ${ }^{73}$ Sementara Islam dan Sapta Darma tidak memiliki sentuhan sejarah apapun.

Penganut Sapta Darma mengakui bahwa ajarannya bukanlah agama tetapi, cara menuju Tuhannya yang dilakukan dengan sujud ening merasakan perubahan pada hati dan jiwanya. Apa yang dirasakan penganut Sapta Darma merupakan pengalaman keagamaan atau spiritualitas yang hanya dirasakan dan diyakini oleh penganut agama. ${ }^{74}$ Pengalaman beragama dapat berdampak pada kepribadian yang disebabkan adanya proses penerimaan dan dialog intensif dengan pemimpin Sapta Darma.

Dialog intensif antara pemimpin agama dan penganutnya melahirkan sikap akomodatif dan memahami pesan-pesan agama yang disampaikan secara utuh. ${ }^{75}$ Spiritualitas Sapta Darma telah menyatu dan menjiwai para penganutnya yang sesungguhnya diawali dengan problem kehidupan. Solusi yang ditawarkan oleh pemimpin Sapta Darma dan pengaruh yang kuat mampu mengubah pandangan tentang agama sebelumnya (Islam). Kebutuhan sosial ekonomi dan problem kehidupan yang terus menghimpit akhirnya menemukan pelarian yakni, Sapta Darma. Keraguan terhadap agama sebelumnya mulai menimbulkan pertanyaan dan tidak menemukan dalam Islam.

Clifford Geertz mengemukakan bahwa agama merupakan "(1) suatu sistem simbol yang bertujuan untuk (2) menciptakan perasaan dan motivasi yang kuat, mudah menyebar, dan tidak mudah hilang dalam diri seseorang". ${ }^{76}$ Dalam artian

${ }^{70}$ Turita Indah Setyani, Meniti Sinkretisme Teks Tantu Panggělaran, Kawistara, vol 1, no. 2 (August 17, 2011): 133.

${ }^{71}$ Mark, R. Woodward, Islam Jawa: Kesalehan Normatif versus Kebatinan. (Yogyakarta, LkiS, 1999), 2 .

${ }^{72}$ Amri Marzali, “Agama dan Kebudayaan,” Umbara 1, no. 1 (March 23, 2017), 57-75.

${ }^{73}$ Siti Nurmajah, "Relasi Wahyu dalam Tiga Agama Samawi (Kajian terhadap Pemikiran Mohammed Arkoun)," Al-Fikra: Jurnal Ilmiah Keislaman 18, no. 1 (February 10, 2020): 1-11.

${ }^{74}$ Eunil David Cho, "Prayer as a Religious Narrative: The Spiritual Self and the Image of God,” Pastoral Psychology 68, no. 6 (December 1, 2019): 639-649.

${ }^{75}$ Osman Murat Deniz, "Understandings of Theological Conversion in the Interreligious Dialogue," Dialogo 6, no. 1 (2019): 59-69.

${ }^{76}$ Daniel L. Pals, Seven Theories of Religion (Tujuh Teori Agama Paling Komprehensif). (Jogjakarta, IRCiSoD), 342.

Khazanah, Vol. 19 (1), 2021 
bahwa agama semestinya menjadi pandangan hidup dan etos yang muncul sebagai realitas yang unik karena melibatkan emosi, perasaan dan keyakinan yang mengakar kuat sehingga, beragama bukan sekedar rutinitas keagamaan atau kebutuhan spiritual semata. Pindahnya penganut Sapta Darma merupakan keyakinan kebenaran tanpa pembuktian karena, menganut agama yang diyakini sebelumnya tidak dilakukan secara utuh atau rutin. Ibadah yang rutin atau istiqomah memiliki keistimewaan yang luar biasa sebagaimana dijelaskan Ibnu Rajab dalam karyanya Jami' al Ulum wa al Hikam bahwa, istiqomah adalah perilaku lurus dan fokus yang mencakup ketaatan dhohir dan batin dan meninggalkan semua yang dilarang agamanya. ${ }^{77}$

Rutinitas ibadah Islam telah bergeser pada rutinitas sujud ening yang dilakukan para penganut Sapta Darma. Rutinitas sujud mengubah perilaku penganut Sapta Darma menjadi orang yang lebih baik karena, makna sujud dalam Sapta Darma adalah sujud sumarah yang bermakna laku meditasi untuk mendapatkan ketenangan hati sambil berkomunikasi dengan Tuhannya agar, tercapai maksud dan tujuannya. Pola komunikasi spiritual yang dimiliki adalah makna kemanusiaan, ${ }^{78}$ kesadaran ketuhanan, kesadaran batin dan dzikir bermakna sosial.

Sapta Darma menurut sejarah bukanlah agama tetapi, hasil pemikiran dan meditasi seorang manusia bernama Hardjosapoero yang diubah namanya menjadi panuntun agung sri gutama berdiri tanggal 27 Desember 1955. Pendirian Sapta Darma merupakan hasil meditasi atau samadhi dengan menyepi yang diakui sebagai sesuatu yang ghaib kemudian diajarkan untuk mendapatkan ketenangan batin. Penganut Sapta Darma kebanyakan muslim sebagaimana ditemukan dalam penelitian ini mengakui Islam adalah agamanya. Hasil konstruksi sosial terhadap penghayat, secara eksternalisasi Islam adalah agamanya, internalisasi Sapta Darma adalah keyakinannya dan objektivasi Sapta Darma bukanlah sebuah agama tetapi, budaya berbudi pekerti luhur. ${ }^{79}$ Penganut Sapta Darma yang diteliti masih tetap menganut Islam dan belum punya rencana untuk mengubah identitasnya, berbeda dengan tokohnya ingin segera mengubah identitasnya.

Identitas agama menjadi salah satu kajian menarik karena, penganut Sapta Darma masih menginginkan Islam menjadi identitas agamanya. Upaya mempertahankan Islam sebagai agama adalah bukti keraguan terhadap Sapta Darma bukanlah agama tetapi, spirit yang berdampak pola perilaku. Secara administrasi politik Sapta Darma merupakan aliran kepercayaan bukan sebagai agama dan bentuk mempertahankan nilai budaya dari pendirinya Hardjosoepoetro. Dilema politik

\footnotetext{
${ }^{77}$ Mulyono Mulyono, “Keistimewaan Istiqomah Dalam Perspektif Al-Qur’an,” Imtiyaz: Jurnal Ilmu Keislaman 4, no. 1 (May 30, 2020): 1-15.

${ }^{78}$ Arini Sa'adah, "Pola Komunikasi Spiritual Dalam Praktik Sujud Aliran Kepercayaan Sumarah (Pendekatan Fenomenologi Paguyuban Sumarah Di Kabupaten Ponorogo)" (diploma, IAIN PONOROGO, 2019), accessed July 6, 2020, http://etheses.iainponorogo.ac.id/8414/.

${ }^{79}$ Faizal Azis, "Konstruksi Sosial Penghayat Kerohanian Sapta Darma (Ksd) Terhadap Ajaran Kepercayaan Sapta Darma dalam Kehidupan Sosial (Studi di Sanggar Agung Candi Busana Sapta Darma Kecamatan Pare Kabupaten Kediri)" (skripsi, Universitas Airlangga, 2017), accessed February 2, 2020, http:/ /ib.unair.ac.id.
} 
agama dapat terjadi pada siapa saja sebagaimana pada kasus Kuil Yasukuni di Jepang untuk mempertahankan agama Shinto. ${ }^{80}$ Nilai-nilai budaya yang dilahirkan dari sebuah kepercayaan telah melekat pada penganut Sapta Darma.

Agama dan spiritualitas adalah dua hal yang berbeda, agama atau religiusitas memiliki konsep dasar ketuhanan (teologi ketuhanan) sesuai dengan agama tertentu, memiliki praktik atau cara beribadah dan berfungsi membantu individu memahami pengalaman hidupnya. Spiritualitas tidak memiliki dasar keyakinan teologis maupun praktik ibadah tertentu tetapi, berfungsi memahami pengalaman hidupnya. ${ }^{81}$ Sapta Darma memfokuskan pada pengalaman hidup dan mencari ketenangan melalui meditasi sujud atau ening sebagai interpretasi budaya. Agama dan budaya antara Islam dan Sapta Darma terjalin harmonisasi dengan motif dan tujuan yang disebut dengan Islam eklektik. ${ }^{82}$

Islam sebagai agama memiliki dasar keyakinan teologi ketuhanan serta memiliki spiritualitas hidup dengan mengimplementasikan setiap gerakan ibadah yang diwajibkan bagi setiap muslim. Ibadah vertikal untuk senantiasa mengagungkan Allah dengan ritual atau ajaran Islam yang tertuang dalam rukun Islam dan rukun iman serta ibadah sosial sebagai kekuatan membangkitkan spiritualitas Islam di era modern. ${ }^{83}$ Umat Islam secara bertahap dan pasti terus meningkatkan kualitas iman agar, tidak tergerus atau tertipu dengan spiritualitas tanpa teologi ketuhanan.

Budaya santun atau berakhlak mulia merupakan ajaran Islam yang menjadi identitas umat Islam dengan terus membumikan nilai-nilai yang terkandung dalam alqur'an. Islam Nusantara yang menjadi ciri khas bangsa Indonesia mengakomodasi masyarakat dengan budaya lokalnya ${ }^{84}$ tetapi, tidak menjustifikasi identitas/ ideologi/ aliran tertentu masuk menjadi aliran Islam. Spiritualitas yang ditemukan dalam Sapta Darma adalah keragaman budaya dalam mencari identitas yang berbeda dengan yang lain. Di era modern, masih terdapat manusia yang memiliki kekuatan gaib, artinya bersekutu dengan makhluk ghaib atau merasakan memiliki kekuatan sebagaimana diyakini penganut Sapta Darma. Karena itu, membiarkan dengan membatasi identitas agama masih menjadi perhatian pemerintah.

Masyarakat diberi kebebasan memilih agama dan kepercayaan sesuai dengan keyakinannya. Kebimbangan yang dialami menjadi problem kehidupan penganut Sapta Darma yang harus segera menemukan jawabannya untuk memilih salah satunya. Agama atau kepercayaan atau dibiarkan dalam pencarian sampai saatnya

${ }^{80}$ Masa'aki, "The Politico-Religious Dilemma of The Yasukuni Shrine."

${ }^{81}$ Yulmaida Amir and Diah Rini Rismawati, "Religiusitas dan Spiritualitas: Konsep Yang Sama Atau Berbeda?," Jurnal Ilmiah Penelitian Psikologi: Kajian Empiris \& Non-Empiris 2, no. 2 (2016): $67-73$.

\footnotetext{
${ }^{82}$ Wiwik Setiyani, Harmonisasi Agama dan Budaya: Makna Tindakan Tlasib 87 di Sumbergirang Mojokerto Jawa Timur (Surabaya: Disertasi UINSA, 2015) http://pasca.uinsby.ac.id/catalog/index.php?p=show_detail\&id=11558\&keywords=

${ }^{84}$ Lestari Lestari, "Islam Nusantara Corak Spiritualitas Pribumi," Jurnal Elkatarie : Jurnal Ilmu Pendidikan dan Sosial 1, no. 02 (August 19, 2019): 28-41.
} 
memilih. Masyarakat atau pemerintah tidak melakukan diskriminasi atau intimidasi terhadap agama atau kepercayaan minoritas. Kebebasan beragama untuk berkeyakinan terhadap adanya Tuhan yang maha Esa adalah implementasi nilai-nilai Pancasila dan bagian dari hak asasi manusia ${ }^{85}$ yang harus ditegakkan dan dipilih melalui identitas masing-masing individu masyarakat.

Situasi yang dialami para penganut Sapta Darma merupakan proses pencarian jati diri ditengah agama sinkretik untuk menemukan konsep agama yang tepat. Seiring dengan perkembangan era modern religiusitas dan spiritualitas memiliki hubungan yang saling menguatkan. Religiusitas merupakan aktivitas doktrinal yang dilakukan individu pada ritual keagamaan. Spiritualitas adalah entitas individu yang berkaitan dengan pengenalan diri dengan $\operatorname{Tuhan}^{86}$ dan eksistensi diri sebagai ekspresi keyakinan. Doktrin ajaran agama dapat melahirkan pribadi yang religius dengan nilainilai spiritualitas yang dapat diimplementasikan pada ibadah sosial atau kehidupan sosial yang bertanggungjawab. ${ }^{87}$

Bentuk sinkretisme antara Islam dan Sapta Darma terlihat pada klaim bahwa Sapta Darma bukanlah agama tetapi, hasil pemikiran dan meditasi atau samadhi seorang manusia yang diakui sebagai sesuatu yang ghaib dan diajarkan untuk mendapatkan ketenangan batin. Selain itu, penganut Sapta Darma dihadapkan pada pergulatan yang mempertemukan antara dua agama dan budaya yang menempatkan mereka pada pilihan yang rumit. Sinkretisme sebagai bagian dari aspek kehidupan menjadikan penganut Sapta Darma dapat menjadi bagian dari proses kehidupan dalam mencari dan menemukan jati diri. Dialog dan pertemuan yang intensif dengan tokoh agama atau ulama/ kiai dapat menjadi solusi alternatif agar, tidak jatuh dalam kebimbangan dan kecemasan guna membangkitkan dan menguatkan keyakinan. Refleksi atau perenungan diri tentang kesadaran beragama bukan kesadaran berbudaya harus diutamakan guna menemukan jati diri. Meski agama dan budaya merupakan dua hal yang saling berkaitan ${ }^{88}$ tetapi, berbeda diantara keduanya. Secara teoritis, paham Sinkretisme pada dasarnya kurang berorientasi pada proses yang dinamis karena hanya konsen pada hasil pertemuan dua entitas nilai (suatu budaya atau agama) sehingga kurangnya keseimbangan di dalamnya

\section{Simpulan}

Sosio-religi pada komunitas Sapta Darma di Surabaya merupakan cerminan masyarakat marginal (masyarakat yang teralienasi) memerlukan perhatian dari

\footnotetext{
${ }^{85}$ Victorio H. Situmorang, "Kebebasan Beragama Sebagai Bagian dari Hak Asasi Manusia," Jurnal HAM 10, no. 1 (July 19, 2019): 57-67.

${ }^{86}$ Denny Najoan, "Memahami Hubungan Religiusitas Dan Spiritualitas Di Era Milenial," Educatio Christi 1, no. 1 (January 30, 2020): 64-74.

${ }^{87}$ Husain Heriyanto, "Spiritualitas, Transendensi Faktisitas, Dan Integrasi Sosial," Khazanah: Jurnal Studi Islam Dan Humaniora 16, no. 2 (January 7, 2019): 145-75, https://doi.org/10.18592/khazanah.v16i2.2384.

${ }^{88}$ Marzali, “Agama dan Kebudayaan.”
} 
lembaga keagamaan. Pelarian akibat kendala ekonomi dan frustasi terhadap problem kehidupan memiliki kecenderungan untuk mengisolasi diri dan bertemu dengan orang-orang yang senasib. Sapta Darma mengedepankan keluhuran akhlak sehingga, menjadi daya tarik masyarakat tanpa diskriminasi. Sosio-religi penganut Sapta Darma merupakan proses pencarian jati diri yang belum selesai akibat problem kehidupan yang tertekan.

Implementasi ajaran Islam dan Sapta Darma dilakukan oleh penganut sapta darma sebagai ritual ibadah. Islam sebagai identitas tetapi, diakui sebagai agama sab atau resmi yang membuat nyaman dan terlindungi. Aktivitas ritual Islam masih dilakukan sebagai kewajiban seorang muslim untuk menjalankan syariatnya. Implementasi Sapta Darma dilakukan dengan sujud atau ening secara rutin bersama pemimpinnya dengan pertemuan intensif sebagai jalannya mencari ketenangan. Kedekatan dengan pemimpin Sapta Darma melahirkan empati dan simpati yang dijadikan sebagai figur keteladanan dan sumber inspirasi. Islam dan Sapta Darma dua ajaran yang berbeda, masing-masing memiliki spiritualitas yang dapat dirasakan oleh penganutnya. Doktrin ajaran Islam bersumber pada alquran dan hadis yang disampaikan oleh nabi Muhammad saw. sementara, Sapta Darma merupakan hasil interpretasi perenungan manusia yang diajarkan oleh Hardjosoepoetro dari Pare Kediri dengan titi laku atau meditasi.

Islam dan Sapta Darma merupakan dua hal yang berbeda pada aspek ajaran dan ritualnya. Agama dan spiritualitas adalah relasi yang saling menguatkan karena, Islam memiliki nilai-nilai spiritualitas bagi muslim yang melekat pada penganutnya. Lebih daripada itu, bentuk sinkretisme dalam studi ini dapat dilihat pada tiga point; pertama, Sapta Darma merupakan ajaran hasil interpretasi pemikiran manusia yang menjadi budaya di masyarakat. Kedua, penganut Sapta Darma menilai kepercayaan (Sapta Darma) bukanlah agama tetapi, bagian dari penghayat kepercayaan. Ketiga, menjadikan Islam tetap sebagai identitas dan Sapta Darma menjadi kepercayaan atau jalannya. Kendati sinkretisme antara Islam dan Sapta Darma begitu terasa namun, kondisi ini mendorong mereka mempertahankan kedua agama tersebut karena, menemukan apa yang ingin dicapai oleh setiap insan yaitu, kesejahteraan dan keseimbangan spiritualitas. Hal ini menjadikan Islam dan Sapta Darma bukan sebagai pelarian hidup semata tetapi, sebaliknya yakni, sebagai jalan hidup.

Eksistensi diri dan ekspresi keagamaan Sapta Darma cukup berpengaruh bagi penganutnya khususnya bagi muslim. Proses perenungan dan pilihan keyakinan beragama sebaiknya dilakukan dengan pertemuan secara intensif dengan tokoh agama atau Kiai guna meneguhkan keyakinan dalam beragama. Tujuannya untuk menghindari salah tafsir dan terjadinya kemungkinan-kemungkinan lain seperti; menomorsatukan atau mengklaim agama tertentu sebagai yang paling benar secara berlebihan hingga, melenceng dari etos keberagamaan atau, overlapping antara agama yang satu dengan agama yang lain hingga alienasi agama. 


\section{Daftar Pustaka}

Abdillah, Arafat Noer. "Pemberdayaan Mualaf Pasca Konversi di Mualaf Center Yogyakarta." Jurnal Tarbiyatuna 11, no. 1 (June 1, 2020): 23-30.

Abdullah, Mulyana. "Meneladani Sifat-Sifat Malaikat Allah Sebagai Bentuk Mengimani Adanya Malaikat" 16, no. 2 (2018): 10.

Ali, Maulana Muhammad, Darul Kutubil Islamiyah, desainbuku.com, studiquran.com, and okebook. Islamologi: Panduan Lengkap Memahami Sumber Ajaran Islam, Rukun Iman, Hukum \& Syariat Islam. Darul Kutubil Islamiyah, n.d.

Al-Wasithi, Abu Fatiah Al Adnani \& Abdur Rahman. Renungan Akbir Zaman. QultumMedia, 2008.

Amir, Yulmaida, and Diah Rini Lesmawati. "Religiusitas Dan Spiritualitas: Konsep Yang Sama Atau Berbeda?" Jurnal Ilmiah Penelitian Psikologi: Kajian Empiris \& Non-Empiris 2, no. 2 (2016): 67-73.

Arifin, Nur. "Motif Bergabung Dalam Aliran Sapta Darma Pengikut Ajaran Di Sanggar Agung Candi Sapta Rengga Yogyakarta." Jurnal Sosiologi Agama 11, no. 1 (January 21, 2018): 35-56.

Benda, Harry J. The Crescent and Rising Sun; Indonesian Islam Under Japanese Occupation, 1942-1945. The Hague and Bandung, W. Van Hoeve, 1958, 320 pp. (Book Reviews), 126-134.

Chikmawati, Putri. "Konsep Manusia Dalam Ajaran Sapta Darma Dan Pemikiran Drijarkara." Undergraduate, UIN Sunan Ampel Surabaya, 2018. http://digilib.uinsby.ac.id/23120/.

Cho, Eunil David. "Prayer as a Religious Narrative: The Spiritual Self and the Image of God.” Pastoral Psychology 68, no. 6 (December 1, 2019): 639-649.

Christimoty, Debora Nugrahenny. "Teologi Ibadah dan Kualitas Penyelenggaraaan Ibadah: Sebuah Pengantar." Pasca: Jurnal Teologi dan Pendidikan Agama Kristen 15, no. 1 (November 30, 2019): 1-7.

Deniz, OM. "Understandings of Theological Conversion in the Interreligious Dialogue." Dialogo 6, no. 1 (2019): 59-69.

Dewi, Ernita. "Transformasi Sosial dan Nilai Agama." Substantia: Jurnal Ilmu-Imu Ushuluddin 14, no. 1 (April 11, 2012): 112-121.

Fahham, Achmad Muchaddam. "Penyelenggaraan Ibadah Haji: Masalah Dan Penanganannya." Kajian 20, no. 3 (September 19, 2016): 201-218.

Faizal Azis. "Konstruksi Sosial Penghayat Kerohanian Sapta Darma (KSD) Terhadap Ajaran KSD Dalam Kehidupan Sosial (Studi di Sanggar Agung Candi Busana Sapta Darma Kecamatan Pare Kabupaten Kediri)." Skripsi, Universitas Airlangga, 2017. http://lib.unair.ac.id. 
Francesco, Chirico. "Spiritual Well-Being In 21st Century: It Is Time to Review the Current WHO's Health Definition" Journal of Health and Social Science 1, no. 1 (March 15, 2016): 11-16.

Geertz, Cliffert. The Religion of Java. University of Chicago Press, 1976.

Hajjaj, Jihad Muhammad. Umur dan Silsilah Para Nabi. Qisthi Press, 2016.

Hamidah, Allinda. "Pembentukan Keimanan Kepada Allah Berbasis Prophetic Learning Untuk Siswa Sekolah Dasar." Cendekia 10, no. 01 (March 23, 2018): $15-28$.

Hamimah, Siti. "Dinamika Kasus Ahmadiyah Dan Aliran Kepercayaan Lainnya Serta Penyelesaiannya Melalui Hukum Tertulis Di Indonesia." Syariab: Jurnal Hukum dan Pemikiran 18, no. 1 (June 30, 2018): 19-29.

Hantoro, Andriawan Bagus, and Abraham Nurcahyo. "Studi Perkembangan Aliran Kebatinan Kerohanian Sapta Darma Di Kabupaten Magetan Tahun 19562011.” Agastya: Jurnal Sejarah Dan Pembelajarannya 4, no. 02 (July 10, 2014): 54 73.

Haris, Andi, Asyraf Bin AB Rahman, and Wan Ibrahim Wan Ahmad. "Mengenal Gerakan Sosial dalam Perspektif Ilmu Sosial." Hasanuddin Journal of Sociology 1, no. 1 (July 3, 2019): 15-24.

Himawari, Ni Made Rasmi, Titik Muti'ah, and Hartosujono Hartosujono. "Spiritual Well-Being Penganut Aliran Kepercayaan Sapta Darma." Jurnal Spirits 9, no. 2 (December 26, 2019): 63-74-74.

Ibrahim, Anwar, Muhammad Sarbini, and Ali Maulida. "Implementasi Metode Pembiasaan Shalat Tahajud Dan Puasa Senin-Kamis Pada Pembentukan Akhlak Karimah di Sekolah Unggulan Islami (Suis) Leuwiliang Bogor." Prosa PAI: Prosiding Al Hidayah Pendidikan Agama Islam 1, no. 2B (April 16, 2019): 130-143.

al-Jauziyyah, Ibnul Qayyim. Qadha dan Qadar. Qisthi Press, 2016.

Jong, Kees de. "Hidup Rukun Sebagai Orang Kristen Spiritualitas Dari Segi Theologia Religionum." Gema Teologi 30, no. 2 (October 10, 2006).

Jung, Carl Gustav. The Spirit in Man, Art, and Literature: Betapa Dabsyatnya Spirit Manusia. IRCiSoD, n.d.

Kahar, Abd. "Eksistensi Dan Keistimewaan Malaikat Jibril AS Dalam Al-Qur'an." Jurnal Pemikiran dan Ilmu Keislaman 2, no. 1 (September 15, 2018): 283-325.

Khasbullah, Wiwik Setiyani. "Dilema Keberagamaan Muslim Pengikut Sapta Darma Dalam Menemukan Nilai-Nilai Spiritualitas.” Religi: Jurnal Studi Agama-agama 16, no. 2 (August 30, 2020): 167-187.

Lestari, Lestari. “Islam Nusantara Corak Spiritualitas Pribumi." Jurnal Elkatarie: Jurnal Ilmu Pendidikan dan Sosial 1, no. 02 (August 19, 2019): 28-41.

Mahmud, Mahmud. "Pola Asuh Orang Tua Dalam Membina Kemampuan Membaca Al-Quran Pada Anak di Desa Padang Tanggul Kecamatan Amuntai Selatan." 
Al Qalam: Jurnal Ilmiah Keagamaan dan Kemasyarakatan 14, no. 1 (June 1, 2020): 95-108.

Mahmuddin, Ronny, Irsyad Rafi, Khaerul Aqbar, and Azwar Iskandar. "Hukum Menyegerakan Penyerahan Zakat Harta Dan Zakat Fitrah Di Saat Pandemi Covid-19.” Bustanul Fuqaha: Jurnal Bidang Hukum Islam 1, no. 2 (May 5, 2020): 125-136.

Marzali, Amri. "Agama dan Kebudayaan." Umbara 1, no. 1 (March 23, 2017). Accessed July 2020. http://journal.unpad.ac.id/umbara/article/view/9604.

Masa'aki, Shinya. "The Politico-Religious Dilemma of The Yasukuni Shrine." Politics and Religion Journal 4, no. 1 (2010): 41-55.

Mawaza, Jayyidan Falakhi, and Rohit Mahatir Manese. "Pengikut Sapta Darma di Tengah Pluralitas Terbatas." Palita: Journal of Social Religion Research 5, no. 1 (April 26, 2020): 49-64-64.

Muh. Luthfi Anshori, 3501408021. "Laku Spiritual Penganut Ajaran Kerokhanian 'Sapta Darma' (Kasus Sanggar Candi Busono Kec. Kedung Mundu, Semarang)." Other, Universitas Negeri Semarang, 2013 https://lib.unnes.ac.id/18191/.

Muhammad, Nurdinah. "Memahami Konsep Sakral dan Profan dalam AgamaAgama." Substantia: Jurnal Ilmu-Ilmu Ushuluddin 15, no. 2 (October 15, 2013): 266-278.

Mulyono, Mulyono. "Keistimewaan Istiqamah Dalam Persfektif Al-Qur'an.” Imtiyaz: Jurnal Ilmu Keislaman 4, no. 1 (May 30, 2020): 1-15.

Naim, Ngainun. "Kebangkitan Spiritualitas Masyarakat Modern." Kalam 7, no. 2 (December 31, 2013): 237-258.

Najoan, Denny. "Memahami Hubungan Religiusitas Dan Spiritualitas Di Era Milenial." Educatio Christi 1, no. 1 (January 30, 2020): 64-74.

Nurmajah, Siti. "Relasi Wahyu dalam Tiga Agama Samawi (Kajian terhadap Pemikiran Mohammed Arkoun).” Al-Fikra: Jurnal Ilmiah Keislaman 18, no. 1 (February 10, 2020): 1-11.

Putra, Andi Eka. "Konsep Ahlul Al-Kitab Dalam Al-Qur'an Menurut Penafsiran Muhammed Arkoun Dan Nurcholish Madjid (Sebuah Telaah Perbandingan)." Al-Drikra: Jurnal Studi Ilmu al-Qur'an dan al-Hadits 10, no. 1 (2016).

Royanulloh, and Budi Yahya Haerudin. "Rutinitas Shalat Sebagai Penguat Self Control Untuk Meningkatkan Kualitas Kesehatan Jiwa." Madani 1, no. 2 (December 7, 2019): 172-183.

Sa'adah, Arini. "Pola Komunikasi Spiritual Dalam Praktik Sujud Aliran Kepercayaan Sumarah (Pendekatan Fenomenologi Paguyuban Sumarah Di Kabupaten 
Ponorogo)." Diploma, IAIN Ponorogo, 2019. http://etheses.iainponorogo.ac.id/8414/.

Safitri, Junaidi. "Implementasi Konsep Zakat Dalam Al-Qur'an Sebagai Upaya Mengentaskan Kemiskinan Di Indonesia.” At-Tasyri’ (January 28, 2018): 1 15.

Saleh, Sriwahyuningsih R., Nurul Aini Pakaya, and Chaterina Putri Doni. "Pembentukan Identitas Keagamaan Mahasiswi Bercadar di Perguruan Tinggi Agama Islam di Gorontalo." Madani 1, no. 2 (December 7, 2019): 110-122.

Saraswati, Athaya, and Afrilia Sekar Dewanti. "Stereotip terhadap Aliran Penghayat Sapta Dharma dan Usaha Penganut Sapta Dharma mengatasinya melalui Konsep Diri." Jurnal Audiens 1, no. 1 (March 11, 2020): 58-64.

Setyani, Turita Indah, Meniti Sinkretisme Teks Tantu Pangg laran, Kawistara, vol 1, no. 2 (August 17, 2011): 203-202.

Setiyani Wiwik. Harmonisasi Agama dan Budaya: Makna Tindakan Tlasih 87 di Sumbergirang Mojokerto Jawa Timur. Surabaya: Disertasi UINSA. 2015. http://pasca.uinsby.ac.id/catalog/index.php?p=show_detail\&id=11558\&key words $=$

Shaleh Muhammad, Assingkily et al. "Living Qur'an Dan Hadis di Mi Nurul Ummah (Rutinitas, Ritual Ibadah dan Pembinaan Akhlak)." Ar-Riayah: Jurnal Pendidikan Dasar 4, no. 1 (June 30, 2020): 27-44.

Situmorang, Victorio H. "Kebebasan Beragama Sebagai Bagian dari Hak Asasi Manusia." Jurnal HAM 10, no. 1 (July 19, 2019): 57-67.

Suhandi, Suhandi. "Spiritualitas Agama Dan Masyarakat Modern (Eksistensi Tarekat Qadiriyah Wa Naqsyabandiyah Di Bandar Lampung)." Al-Adyan: Jurnal Studi Lintas Agama 14, no. 1 (June 30, 2019): 71-94.

Switri, Endang, Apriyanti Apriyanti, and Sri Safrina. "Pembinaan Ibadah Shalat (Kaifiatus Sholah / Tata Cara Shalat) Pada TPA Zuryati di Masjid Ummu Massaid Komplek Perumahan the Green Indralaya." Jurnal Anadara Pengabdian Kepada Masyarakat 1, no. 2 (September 25, 2019).

Sya'roni, Muhammad. "Wajah Pendidikan Islam Indonesia." Cendekia 7, no. 01 (May 2, 2015): 15-55.

Tacey, David John. The Spirituality Revolution: The Emergence of Contemporary Spirituality. Psychology Press, 2004.Heriyanto, Husain. "Spiritualitas, Transendensi Faktisitas, Dan Integrasi Sosial." Khazanah: Jurnal Studi Islam Dan Humaniora 16, no. 2 (January 7, 2019): 145-75. https://doi.org/10.18592/khazanah.v16i2.2384.

Khasbullah, Wiwik Setiyani. "DILEMA KEBERAGAMAAN MUSLIM PENGIKUT SAPTA DARMA DALAM MENEMUKAN NILAI-NILAI SPIRITUALITAS.” Religi: Jurnal Studi Agama-Agama 16, no. 2 (August 30, 2020): 167-87. https://doi.org/10.14421/rejusta.2020.1602-03. 
Urrozi, Khoirun Nisa. “Agama Majusi dalam Tinjauan Hadis.” Religious: Jurnal Studi Agama-Agama dan Lintas Budaya 3, no. 2 (November 13, 2019): 147-60. https://doi.org/10.15575/rjsalb.v3i2.4404.

Wahid, Abdul. "Kontribusi Lembaga Adat dalam Implementasi Syariat Islam di Aceh." Jurnal Ilmiah Mizani: Wacana Hukum, Ekonomi dan Keagamaan 6, no. 2 (December 31, 2019): 151-160.

Wahyono S. Bayu, Kejawaan dan Keislaman: Suatu Pertarungan Identitas. Jurnal Ilmu Sosial dan Politik, Vol 5, no, 1 (Juli 2001), 41-59.

Wijayanti, Reni Tiyu. "Pola Perilaku Religius Aliran Kepercayaan Masyarakat Kerokhanian Sapta Darma Di Desa Brengkelan Kecamatan Purworejo Kabupaten Purworejo." Aditya - Pendidikan Bahasa dan Sastra Jawa 3, no. 3 (October 28, 2013): 52-57.

Yuwono, Susatyo. "Mengelola Stres dalam Perspektif Islam dan Psikologi." Psycho Idea 8, no. 2 (July 1, 2010). Accessed July 1, 2020. 